\title{
PERBEDAAN PENGETAHUAN IBU SEBELUM DAN SESUDAH PENDIDIKAN IMUNISASI DASAR DI BPM SUSILAWATI
}

\author{
Meta Rosdiana $^{1}$, Anisah Khoiriah ${ }^{2}$ \\ 1,2.Dosen STIK Siti Khadijah Palembang \\ Program Studi D III Kebidanan STIK Siti Khadijah Palembang \\ Email : rosdiana.meta76@gmail.com
}

\begin{abstract}
ABSTRAK
Imunisasi merupakan suatu tindakan untuk memberikan perlindungan atau kekebalan kepada tubuh bayi dan anak dengan menyuntikkan vaksin atau serum dari suatu penyakit yang telah dilemahkan kedalam tubuh. Imunisasi ini bertujuan untuk melindungi dan mencegah bayi dan anak - anak dari penyakit - penyakit yang menular atau berbahaya. Tujuan dari penelitian ini adalah untuk mengetahui Perbedaan Pengetahuan Ibu Sebelum dan Sesudah Pendidikan Imunisasi Dasar di BPM Susilawati Tahun 2016. Penelitian ini menggunakan desain Pre Ekperimental dengan pendekatan Pre and post test, dengan teknik pengambilan datanya menggunakan kuesioner. Populasi dalam penelitian ini adalah semua ibu yang memiliki bayi usia dibawah 1 Tahun di BPM Susilawati Palembang. Penelitian dilakukan pada Tanggal 22 Mei sampai Tanggal 11 Juni 2016. Pengambilan sampel dilakukan dengan menggunakan random sampling berstrata. Sampel dalam penelitian ini berjumlah 36 orang. Uji statistik yang digunakan dalam penelitian ini adalah Uji Wilcoxon Matched Pair Test. Hasil dari penelitian ini rata-rata skor sebelum pendididkan Imunisasi Dasar 7,00 dengan (95 \% CI : 6,66 - 7,62) dengan standar devisiasi 1,417. Tingkat skor terkecil adalah 5 dan tingkat skor terbesar adalah 10, sedangkan rata-rata skor sesudah pendidikan Imunisasi Dasar 9,00 dengan ( $95 \%$ CI : 8,60 $-9,23$ ) dengan standar divisiasi 0,937. Tingkat skor terkecil adalah 7 dan tingkat skor terbesar adalah 10. Hasil analisa bivariat menunjukan bahwa ada perbedaan pengetahuan sebelum dan sesudah pendidikan imunisasi dasar dengan $P$ value $=0,000$. Dari hasil penilitian ini diharapkan lebih meningkatkan lagi penyuluhan tentang imunisasi dengan penyampaian yang lebih mudah dimengerti oleh ibu sehingga akan menimbulkan pengetahuan ibu yang lebih baik guna meningkatkan atau mencapai kesehatan yang optimal.
\end{abstract}

Kata Kunci : Pendidikan Kesehatan, Pengetahuan, Ibu, Bayi, Imunisasi Daftar Pustaka: 11 (2007 - 2016)

\section{ABSTRACT}

Immunization as an provide to protection or immunity to the body baby and children with injecting the vaccine or serum from a disease that has been attenuated to the body. Immunization aims to protect and to prevent baby and children from diseases infectious or dangerous.The aim of this study is to know the difference of mother knowledge before and after the Basic Immunization education in at private practice midwife Susilawati in 2016. The research of this study used by pre experimental design through pre and post test approach, taking the data of this study used questionnaire. The population at this study is all mothers who has babies under 1 years old age in at private practice midwife Susilawati Palembang. This is study using in 22 may to up and including 11 june 2016. The sample of this study using stratified random sampling, with the total sampling was 36 respondents. The statistical test used in this study is the Wilcoxon Matched Pairs Test. The results of this study the average score before Basic Immunization education was 7.00 ( $95 \%$ CI : 6.66 to 7.62 ) with a standard deviation 
1.417. The level smallest score is 5 and level biggest score is 10 , while the average score after Basic Immunization education was 9.00 ( $95 \%$ CI : 8.60 to 9.23 ) with a standard divisiasi 0.937. The level of the smallest score was 7 and level of the biggest score was 10. The results of the bivariate analysis shows that there are differences in knowledge before and after education Basic Immunization with $P$ value $=0.000$. From the results of this research to hope more the delivery of education about Immunization with a more easily understood by the mother so that it will lead to better knowledge of the mother in order to delivery or achieve optimal health .

Keywords $\quad$ : Health Education, Knowledge, Mother, Baby, Immunization

References $\quad: 11(2007-2016)$

\section{PENDAHULUAN}

World Health Organization (WHO) melaporkan bahwa terjadi penurunan angka kematian balita (AKB) pada tahun 19902013. Pada tahun 1990 kematian balita sebesar 12,6 juta anak, sedangkan pada tahun 2013 kematian balita sebesar 6,3 juta anak (WHO, 2014). Menurut Kemenkes RI (2014) angka kematian balita pada tahun 2015 masih jauh dari target AKB yaitu sebesar 23 per 1000 kelahiran hidup. AKB secara global di dunia masih tinggi yaitu sebesar 46 per 1000 kelahiran hidup (WHO, 2014).

Salah satu cara untuk mengurangi angka kematian pada bayi ataupun anak yaitu memalui pemberian imunisasi. WHO menyebutkan bahwa terdapat 1,5 juta anakmeninggal akibat Penyakit yang Dapat Dicegah Dengan Imunisasi (PD3I) di tahun 2013. Namun pada tahun 2015 lebih dari 1,4 juta anak di dunia meninggal karena PD3I (Kemenkes RI, 2015). Meskipun terjadi penurunan kematian dari tahun sebelumnya, perlu adanya upaya preventif untuk mengatasi PD3I

Istilah imunisasi sudah sangat familiar ditelinga kita. Ada beberapa jenis imunisasi yang telah kita kenal, seperti campak, hepatitis B, BCG, DPT, dan Polio. Imunisasi sangat erat kaitannya dengan sistem kekebalan tubuh. Sehingga, pemberian imunisasi pada anak mempunyai tujuan memberikan kekebalan bantuan pada tubuh terhadap serangan penyakit tertentu, dengan cara memasukan vaksin kedalam tubuh. (Hamidin, 2014)

Orang tua yang bijak akan selalu memberikan prioritas utama untuk melindungi dan memberikan kesehatan yang terbaik bagi anaknya. Pemberian imunisasi sejak bayi lahir, akan memberikan perlindungan terhadap berbagai penyakit yang berbahaya. Memberi imunisasi bayi tepat pada waktunya adalah faktor yang sangat penting untuk menentukan keberhasilan imunisasi dan kesehatan bayi (Suririnah, 2009)

Riskesdas (2013) menyatakan bahwa terdapat peningkatan angka cakupan imunisasi dasar lengkap dari tahun 20072013. Pada tahun 2007 angka cakupan imunisasi dasar lengkap sebesar 41,6\% dan pada tahun 2013 angka cakupan imunisasi dasar lengkap meningkat menjadi 59,2\%. Akan tetapi, pada tahun 2013 terdapat cakupan imunisasi dasar tidak lengkap.

Di Sumatera Selatan untuk tahun 2014 target Universal Child Imunization sebesar $100 \%$ desa/kelurahan sesuai kepmenkes nomor 741 tahun 2008 tentang standar pelayanan minimal (SPM) kabupaten/kota

Cakupan kelurahan Universal Child Imunization Data Dinkes Kota Palembang Tahun 2014 belum mencapai target, hanya sebesar $95,53 \%$. Kelurahan yang belum mencapai target berada di Wilayah Kecamatan Ilir Timur I (72,73\%) dan Ilir Timur II $(83,33 \%) 9$ 
Bedasarkan cakupan imunisasi yang diperoleh dari BPM Susilawati cakupan imunisasi dasar pada tahun 2013 yaitu imunisasi BCG berjumlah 210 bayi, DPT berjumlah 422 bayi, Polio 422 bayi, dan imunisasi campak berjumlah 150 bayi, pada Tahun 2014 imunisasi BCG berjumlah 190 bayi, DPT berjumlah 200 bayi, polio berjumlah 200 bayi dan imunisasi campak berjumlah 175 bayi, kemudian pada Tahun 2015 imunisasi BCG berjumlah 198 bayi, DPT berjumlah 250 bayi, Polio berjumlah 250 bayi dan imunisasi campak berjumlah 166 bayi.

Pentingnya imunisasi didasarkan pada pemikiran paradigma sehat bahwa upaya promotif dan preventif merupakan hal terpenting dalam peningkatan status kesehatan, salah satu upaya preventif yaitu meningkatkan cakupan imunisasi dan kelengkapan imunisasi.

\section{METODE PENELITIAN}

Penelitian ini menggunakan desain Pre eksperimental dengan pendekatan pre and post test dengan menghubungkan sebab akibat yang dilakukan dengan cara memberikan pre test sebelum intervensi dan post test sesudah dilakukan intervensi.. Sampel dalam penelitian ini adalah ibu yang memiliki bayi dibawah usia 1 tahun. Penelitian ini dilaksanakan pada Tanggal 22 Mei sampai 11 Juni Tahun 2016. Alat ukur dalam penelitian ini adalah kuesioner. Uji statistiknya menggunakan Wilcoxon Matched Pair Test. Dalam penelitian ini, pengambilan sampel ditentukan dengan menggunakan accidental sampling atau conveince sampling.

\section{HASIL DAN PEMBAHASAN}

\section{Hasil Penelitian}

\section{Analisis Univariat}

Tabel 5.3.1
Distribusi Responden Berdasarkan Median Pengetahuan Responden Sebelum Diberikan Pendidikan Imunisasi Dasar di BPM Sisilawati Tahun 2016

\begin{tabular}{lccc}
\hline \multicolumn{1}{c}{ Variabel } & $\begin{array}{c}\text { Medi } \\
\text { an }\end{array}$ & $\begin{array}{l}\text { Min }- \\
\text { Max }\end{array}$ & $\begin{array}{c}\text { 95\% } \\
\text { CI }\end{array}$ \\
\hline $\begin{array}{l}\text { Pengetahuan } \\
\text { responden } \\
\text { sebelum } \\
\text { pendidikan }\end{array}$ & & & \\
Imunisasi Dasar & & & \\
\hline
\end{tabular}

Hasil analisa didapatkan rata-rata skor pengetahuan responden sebelum pendidikan Imunisasi Dasar adalah 7,00 dengan standar devisiasi 1,147. Skor terkecil adalah 5 dan skor terbesar adalah 10. Dari hasil estimasi didapat hasil bahwa $95 \%$ diyakini bahwa rata-rata skor pengetahuan responden sebelum pendidikan kesehatan adalah 6,66-7,62.

Tabel 5.3.2

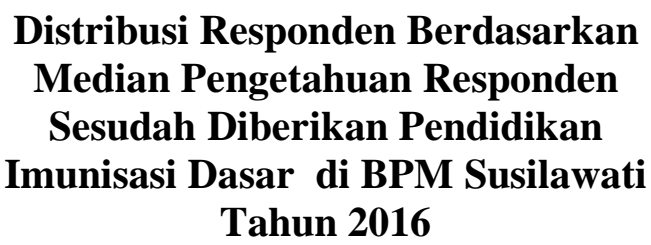

\begin{tabular}{lclc}
\hline \multicolumn{1}{c}{ Variabel } & Median & $\begin{array}{l}\text { Min - } \\
\text { Max }\end{array}$ & $\begin{array}{c}\text { 95\% } \\
\text { CI }\end{array}$ \\
\hline Pengetahuan & & & \\
responden & & & \\
sesudah & 9,00 & $7-10$ & $8,60-$ \\
pendidikan & & & 9,23 \\
Imunisasi & & & \\
Dasar & & & \\
\hline
\end{tabular}

Hasil analisa didapatkan rata-rata skor pengetahuan responden setelah pendidikan Imunisasi Dasar adalah 9,00 dengan standar devisiasi 0,937. Skor terkecil adalah 7 dan skor terbesar adalah 10. Dari hasil estimasi didapatkan hasil bahwa $95 \%$ diyakini bahwa rata-rata skor pengetahuan responden sesudah pendidikan Imunisasi Dasar adalah 8,60-9,23. 


\section{Analisis Bivariat}

Tabel 5.4.1

Perbedaan Pengetahuan Ibu Sebelum dan Sesudah Diberikan Pendidikan Imunisasi Dasar di BPM Susilawati Palembang Tahun 2016

\begin{tabular}{|c|c|c|c|c|}
\hline Variabel & $\mathbf{N}$ & $\begin{array}{l}\text { Mean } \\
\text { Ranks }\end{array}$ & $\begin{array}{c}\text { Sum } \\
\text { Of } \\
\text { Ranks }\end{array}$ & $\begin{array}{c}\mathbf{P} \\
\text { Value }\end{array}$ \\
\hline Sebelum & - & & & 0,000 \\
\hline Sesudah & 0 & 0,00 & 0,00 & \\
\hline Pengetahuan & 32 & 16,50 & 528,00 & \\
\hline Menurun & 4 & & & \\
\hline Pengetahuan & 36 & & & \\
\hline Meningkat & & & & \\
\hline Tetap & & & & \\
\hline Total & & & & \\
\hline
\end{tabular}

Dari tabel diatas terlihat bahwa uji statistic non parametik (wilcoxon matched pair test) didapatkan nilai $\mathrm{p}$ value $=0,000$, karean probabilitas tersebut lebih kecil dari taraf nyata $\alpha=0,05$, maka hipotesis nol (Ho) ditolak, berarti pada alpha $5 \%$ terlihat ada perbedaan yang signifikan rata-rata skor pengetahuan sebelum dan sesudah pendidikan Imunisasi Dasar.

\section{Pembahasan}

Pada hasil analisa didapatkan rata-rata skor pengetahuan responden sebelum pendidikan Imunisasi Dasar adalah 7,00 dengan standar devisiasi 1,147. Skor terkecil adalah 5 dan skor terbesar adalah 10. Dari hasil estimasi didapat hasil bahwa $95 \%$ diyakini bahwa rata-rata skor pengetahuan responden sebelum pendidikan kesehatan adalah 6,66-7,62.

Hasil penelitian ini juga sejalan dengan penelitian yang dilakukan oleh Ulinuha (2013) dengan judul perbedaan pengetahuan ibu yang memiliki bayi tentang imunisasi sebelum dan sesudah diberikan pendidikan kesehatan di Posyandu Mawar 1 Ulu Palembang Tahun 2013 menunjukan bahwa uji statistik yang digunakan Uji Wilcoxon Matched Pairs Test. Berdasarkan hasil uji statistik menunjukan pengetahuan ibu sebelum diberikan pendidikan kesehatan nilai ratarata 13,00 dengan standar devisiasi 1,89. Skor terkecil adalah 11 dan skor terbesar adalah 17. Dari hasil etimasi didapatkan hasil bahwa $95 \%$ diyakini bahwa rata - rata skor pengetahuan responden sebelum pendidikan kesehatan adalah 12,57 - 13,87.

Sesuai dengan temuan teori dari Benyamin bloom (1908) dalam Notoatmodjo 2010 membagi perilaku manusia kedalam tiga wilayah yaitu pengetahuan, sikap, dan keterampilan. Tapi pada perkembangannya teori bloom di modifikasi menjadi dua yaitu pengetahuan dan sikap, dimana pengetahuan ialah hasil dari proses pembelajaran dengan melibatkan indra penglihatan, pendengaran, penciuman dan pengecap. Pengetahuan akan memberikan penguatan terhadap terhadap individu dalam setiap pengambil keputusan dan dalam berperilaku. Menurut Rogers (1974) dalam Notoatmojo 2010 bahwa individu akan melakukan perubahan perilaku dengan mengadopsi perilaku dengan tahapantahapan antara lain; individu mulai menyadari adanya stimulus, individu mulai tertarik dengan adanya stimulus, individu mulai berpikir dan mempertimbangkan, individu mulai mencoba berperilaku baru, individu melakukan perilaku baru. Perilaku yang baru diadopsi oleh individu akan bisa bertahan lama dan langgeng jika individu menerima perilaku tersebut dengan penuh kesabaran, didasari atas pengetahuan yang jelas dan keyakinan.

Pada hasil analisa didapatkan rata-rata skor pengetahuan responden setelah pendidikan Imunisasi Dasar adalah 9,00 dengan standar devisiasi 0,937. Skor terkecil adalah 7 dan skor terbesar adalah 10. Dari hasil estimasi didapatkan hasil bahwa $95 \%$ diyakini bahwa rata-rata skor pengetahuan responden sesudah pendidikan Imunisasi Dasar adalah 8,60 9,23 .

Hasil penelitian ini juga sejalan dengan penelitian yang dilakukan oleh Ulinuha (2013) dengan judul perbedaan 
pengetahuan ibu yang memiliki bayi tentang imunisasi sebelum dan sesudah diberikan pendidikan kesehatan di Posyandu Mawar 1 Ulu Palembang Tahun 2013 menunjukan bahwa uji statistik yang digunakan Uji Wilcoxon Matched Pairs Test. Berdasarkan hasil uji statistik menunjukan pengetahuan ibu sesudah diberikan pendidikan kesehatan nilai ratarata 15 dengan standar devisiasi 1,89019. Skor terkecil adalah 13 dan skor terbesar adalah 19. Dari hasil estimasi dadapatkan hasil bahwa $95 \%$ diyakini bahwa rata - rata skor pengetahuan responden sesudah pendidikan kesehatan adalah 14,5665 15,8710 .

Sesuai dengan teori yang dikemukakan oleh Notoadmodjo (2007), ia mengungkapkan ada enam tingkatan pengetahuan yang terdiri dari : tahu, memahami, aplikasi, analisis, sintesis, dan evaluasi. Dimana tahu diartikan sebagai mengingat suatu materi yang telah dipelajari sebelumnya. Termasuk kedalam pengetahuan tingkat ini adalah mengingat kembali (recall) sesuatu yang spesifik dan seluruh bahan yang dipelajari atau rangsangan yang telah diterima.

Memahami diartikan sebagai suatu kemampuan untuk menjelaskan secara benar tentang objek yang diketahui, dan dapat menginterprestasikan materi tersebut secara benar. Orang yang telah paham terhadap objek atau materi harus dapat menjelaskan, menyebutkan contoh, menyimpulkan, meramalkan, dan sebagainya terhadap objek yang dipelajari.

Aplikasi diartikan sebagai kemampuan untuk menggunakan materi yang telah dipelajari pada situasi atau kondisi real (sebenarnya). Analisis adalah suatu kemampuan untuk menjabarkan materi atau suatu objek kedalam komponenkomponen, tetapi masih didalam satu struktur organisasi, dan masih ada kaitannya satu sama lain. Sintesis menunjukan pada suatu kemampuan untuk meletakan atau menghubungkan bagianbagian didalam suatu bentuk keseluruhan yang baru.
Berdasarkan uji statistik nonparametik dengan wilxocon matched pair test. Didapatkan hasil ada pengaruh yang signifikan antara pengetahuan sebelum dan sesudah diberikan pendidikan Imunisasi Dasar $(p$ value $=0,00)$ dengan pengetahuan menurun setelah mendapatkan pendidikan tentang Imunisasi Dasar ada 0 responden, dengan pengetahuan meningkat setelah mendapatkan pendidikan tentang Imunisasi Dasar ada 32 responden, sedangkan pengetahuan yang tetap setelah mendapatkan pendidikan tentang Imunisasi Dasar adalah 4 responden.

Hasil penelitian ini juga sejalan dengan penelitian yang dilakukan oleh Ulinuha (2013) dengan judul perbedaan pengetahuan ibu yang memiliki bayi tentang imunisasi sebelum dan sesudah diberikan pendidikan kesehatan di Posyandu Mawar 1 Ulu Palembang Tahun 2013 menunjukan bahwa uji statistik yang digunakan Uji Wilcoxon Matched Pairs Test. Didapatkan hasil ada pengaruh yang signifikan antara pengetahuan sebelum dilakukan pendidikan kesehatan dan pengetahuan sesudah dilakukan pendidikan kesehatan $(P$ value $=0,000)$. Dengan pengetahuan meningkat setelah mendapatkan pendidikan kesehatan tentang Imunisasi adalah 32 responden.

Menurut pendapat peneliti bahwa responden yang belum mendapatkan pendidikan tentang Imunisasi Dasar ternyata skor pengetahuannya lebih kecil dibandingkan dengan setelah diberikan pendidikan tentang Imunisasi Dasar. Semua itu dikarenakan responden kurang mendapatkan informasi kesehatan tentang Imunisasi Dasar. Namun setelah diberikan informasi kesehatan tentang Imunisasi Dasar berupa penyuluhan dengan penyampaian materi yang mudah dimengerti oleh Ibu - Ibu dan diajak berdiskusi, membuat responden mudah dalam menerima informasi yang diberikan tentang Imunisasi Dasar sehingga pengetahuan Ibu semakin bertambah. Dengan pengetahuan ibu yang bertambah 
minat ibu untuk membawa anaknya Imunisasi Dasar pun semakin baik.

Dengan demikian, dengan adanya informasi kesehatan, bukan hanya pengetahuan ibu yang semakin bertambah namun kesehatan masyarakat terutama anak pun semakin meningkat, adapaun manfaat penyuluhan ini sangat besar dan banyak manfaatnya salah satunya ialah tresponden akan banyak mendapatkan infomasi serta lebih memahami dan mengerti apa itu Imunisasi Dasar, manfaat Imunisasi Dasar, pentingnya Imunisasi Dasar bagi Bayi, dan Jadwal pemberian Imunisasi Dasar.

\section{KESIMPULAN DAN SARAN}

Rata-rata skor pengetahuan responden sebelum diberikan pendidikan Imunisasi Dasar adalah 7,14 dengan standar devisisasi 1,147, rata-rata skor pengetahuan responden sesudah diberikan pendidikan Imunisasi Dasar adalah 8,92 dengan standar devisisasi 0,937, dan ada perbedaan pengetahuan ibu sebelum dan sesudah diberikan pendidikan Imunisasi Dasar dengan $P$ value $=0,000$. Pengetahuan ibu yang masih kurang ini diharapkan dapat dilakukan peningkatan dengan upaya pemberian penyuluhan tentang imunisasi dasar agar pengetahuan ibu dapat menunjang status imunisasi anak.

\section{DAFTAR PUSTAKA}

BPM Susilawati, 2015. Profil Bidan Praktek Mandiri Susilawati Palembang

Dinkes Kota Palembang, 2014. Profil Kesehatan Dinas Kesehatan Kota Palembang

Dinkes SumSel, 2014. Profil Kesehatan Dinas Kesehatan Sumatera Selatan Hamidin, Aep Syaiful. 2014. Buku lengkap imunisasi alami untuk anak. Yogyakarta: Saufa
Kemenkes RI, 2015. Profil Kesehatan Indonesia Tahun 2014. Jakarta : Kementrian Kesehatan RI 2015

Notoatmodjo. 2007. Pendidikan dan Perilaku Kesehatan. Jakarta: PT Rineka

Notoatmodjo. 2010. Promosi Kesehatan dan Ilmu Perilaku. Jakarta: PT Rineka

Suririnah. 2009. Buku pintar merawat bayi 0-12 bulan. Jakarta: PT Gramedia Pustaka Utama. www.belbuk.com/buku-pintarmerawat-bayi-012-bulan-p7004.html (12 April 2016)

Ulinuha. 2013. perbedaan pengetahuan ibu yang memiliki bayi tentang imunisasi sebelum dan sesudah diberikan pendidikan kesehatan di Posyandu Mawar 1 Ulu. Palembang

WHO, 2014. Immunization. WHO. tersedia di http://www.who.int/topics/immuniz ation/e n/. (14 Mei 2016).

WHO, 2014. Levels and Trends In Child Mortality 2014. WHO. Tersedia di : www.who.int/entity/maternal_child _adoles

cent/documents/levels_trends_child _mortal ity_2014/en/. (16 Mei 2016) 